\title{
Anggaran Pendapatan Belanja Negara (APBN) Prespektif Islam (Studi Kasus APBN di Indonesia Tahun 2014)
}

\author{
Syahirul Alim \\ Khusnuddin
}

\author{
Fakultas Ekonomi Universitas Islam Negeri (UIN) Malang \\ Jl. Gajayana No: 50 Malang
}

Abstrak

Anggaran Pendapatan dan Belanja Negara (APBN) dalam khasanah loterasi Islam sering disebut sebagai Baitul Mal. Baitul Mal adalah pos yang dikhususkan untuk semua pemasukan dan penegeluaran harta yang menjadi hak kaum muslimin/warga Negara. Setiap harta yang menjadi hak kaum muslimin, baik diambil dari kaum muslim dan non-muslim menjadi harta baitul mal. Terdapat tiga paradigm dasar yang selalu menyandera APBN pada system ekonomi kapitalis/neoliberalis yaitu, asumsi makro ekonomi, konsep anggaran berimbang atau anggaran deficit, dan liberalisasi ekonomi. Penyusunan baitul mal menggunakan paradigm yang berbeda. Diantaranya; tidak dibuat setiap tahun, tidak membutuhkan pembahasan dengan Majelis Umat (DPR/MPR), sumber pendapatan dan pos pengeluaran ditetapkan oleh syariah. Khalifah sebagai kepala Negara bias menyusun sendiri melalui hak tabbani, dan alokasi dana masing-masing sumber pendapatan dan pos pengeluaran diserahkan kepada pendapat dan ijtihad khalifah.

Kata kunci: APBN, ekonomi kapitalis, baitul mal, khalifah. 